\title{
Water Sustainability in Campus: A Framework in Optimizing Social Cost
}

\author{
Ahmad Bashawir Abdul Ghani, Nor Idayu Mahat, Azham Hussain, Sany Sanuri Mohd Mokhtar
}

\begin{abstract}
This paper aims to share a framework developed by Universiti Utara Malaysia (UUM) in an effort to build a community that cares for the sustainability of the campus, in particular, the water management. Generally, UUM has about 4 thousand staff and 32, 279 students in the campus. In contrast to other universities, about $95 \%$ of UUM students live at the incampus accommodations provided by the University. Hence, clean water is one of the basic necessities needed by the UUM community. Despite of this necessity, the distribution of water in the campus recorded some loss due to leakage. The implication to this problem is not only affecting the cost of distributing the water to users, but also the total cost to citizens in the campus that consume the water. In addition, UUM is also traced by several river trunks which has become iconic attractions of the campus. However, these rivers are exposed to the risk of pollutions caused by human negligence. Therefore, it is time for the university to take serious actions to prevent more damages done to the rivers in order to ensure the continuity of social life in the campus. On the basis of this concern, UUM has taken steps to develop a framework that seeks to optimize social costs for water sustainability in the future.
\end{abstract}

Keywords: Green campus, sustainability, social cost, water management.

\section{INTRODUCTION}

This paper is prepared to disseminate UUM commitments and contributions on preserving natural resources surrounding the campus for better and healthy living. The focus of the discussion is narrowed down to water management, which is one of the initiatives that is aggressively dealt by the university. UUM put an effort to preserve the rivers and protect clean water for citizens' consumption for many years. Like other basic necessities, having good water management will fulfill citizens' needs on the resource and in return will give good value to the university through quality of work. In reality, UUM faces some challenges in securing clean water for the campus partly due to geographical reason as in Fig. 1. Hilly terrain and surrounded by green forests are some of the challenges that were faced by the university when executing plumbing works to inflict slightest impact on the environment. In addition to that, rusted pipes have noticeably affected the quality of water in terms of colors and odors.

Revised Manuscript Received on June 22, 2019.

Ahmad Bashawir Abdul Ghani, Chancellory, Universiti Utara Malaysia, 06010 UUM Sintok, Kedah, MALAYSIA

Nor Idayu Mahat, Center for Testing, Measurement and Apprisal, Universiti Utara Malaysia, 06010 UUM Sintok, Kedah, MALAYSIA

Azham Hussain, School of Computing, Universiti Utara Malaysia, 06010 UUM Sintok, Kedah, MALAYSIA

SanySanuriMohd Mokhtar, School of Business Management, Universiti Utara Malaysia, 06010 UUM Sintok, Kedah, MALAYSIA
Meanwhile, leakage of water has recorded the amount of loss that need to be borne by the university. All these demands require for quick actions that need to be taken in order to avoid the university from losing too much from the mistakes created by our own mis-management.

In 2018, UUM has started to synchronize all initiatives and activities related to green and sustainability in campus. The synchronization is aiming at optimizing all resources and capacities in the university in achieving one goal university sustainability. The output that can be measured from this effort is obviously the operational cost. After years of managing water resources, UUM has seriously given into immense attention on water management in campus by estimating the right cost in managing the water, as well as social cost. Social cost includes both the private costs and any other external costs to society arising from the production or consumption of a good or service [Federal Reserve Bank San Francisco, 2019].Obviously, most people only consider a private cost involved when executing any sustainability project, such as how much savings can be made if the suppliers reduced the water leakage in water distribution. The suppliers often neglect to estimate how much are the impact on citizens and environment due to the leakage. This project is currently executed in UUM as a mission to produce more observant citizens on water sustainability and to become more responsible leader in preserving water resources for the wellbeing of the world.

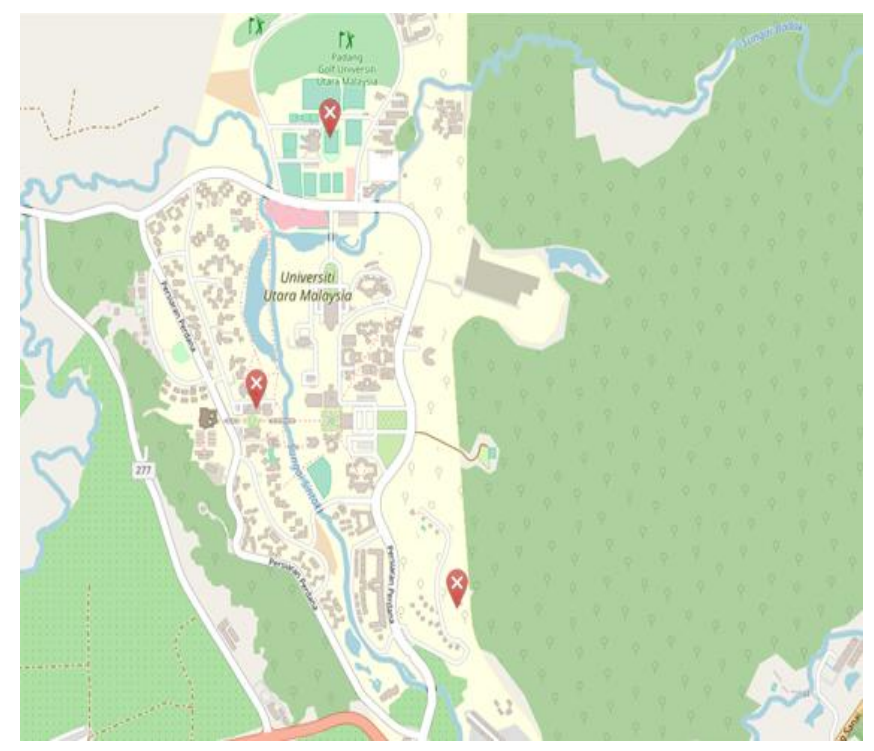

Fig. 1 Natural water resources in the Universiti Utara Malaysia 


\section{CHALLENGES AND LESSONS FROM WATER MANAGEMENT}

Below are some explanation on challenges and lessons learned during this study.

\section{Protection on clean water}

Clean water is very precious to everyone which makes its availability and quality as essential needs. The demand for clean water in Malaysia for the year 2016 has increased to 377 million liters per day as compared to 16,536 million liters per day [Department of Statistics Malaysia, 2017]. Clean water has been the university's focus, among other necessities, in line with Sustainable Development Goals (SDG), which is to provide equitable safe water and improve water quality stated in the indicator that includes in clean water and sanitation area. The Department of Irrigation and Drainage (JPS) has implemented river mitigation project for Sintok River and Badak River through degrading and upgrading existing lake/pool, upgrading existing spillways and construction of rock groins.

Since the university is covered by green ecosystem, which lead to be named as the university in a green forest, "Universiti di RimbaHijau", it is easily exposed to pollution issues such as incorrect waste disposal, logging and poor water maintenance, to list a few. Many programs and activities have been done to maintain the ecosystem diversities. River rehabilitation and restoration has been practicedto support SDG intention to protect and restore water related to the ecosystem. Staff and students are encouraged to organize and support university activities towards green campus to ensure the sustainable learning environment.

\section{Water leakages}

Water leakages is a major issue to many regions in the world [Weifeng et al., 2011]. The leakages give significant effects on water supply management, economic loss, and threats for standard of drinking water. Therefore, the solutions for water leakages problems has become an important goal for many countries to reduce the loss. Similarly, in UUM, water leakages have become a threat within the campus water distributions. UUM spends about RM4.9 million (USD1.2 million) to accommodate water usage of almost 4.5 million cubic meters. However, about $15 \%$ of water distribution is loss, which equivalent to RM7 thousand (USD2 thousand) a year. The amount is a huge loss to the university, whereby immediate action plans must be devised and executed to minimize the impact of such loss.

\section{Water conservation}

Figure 2 shows the monthly water usage in UUM campus for the year 2017. With the efforts to understand and reduce water usage, the university takes a serious action by conserving the water. Due to the climate and categorized as one of the countries which has a high annual rainfall with average annual rainfall of $2420 \mathrm{~mm}$, rain water harvesting is the best approached as an initiative for implementing the water conservation programs. Rainwater harvesting (RWH), also known as rainwater harvesting systems or cisterns, are devices that intercept, divert, store, and release collected roof runoff from rainfall for later use as an alternative water supply. In 2018 , over $75 \%$ of collection and storage of the rainwater used as non-portable resource for toilet flushing and garden sprinkler system.

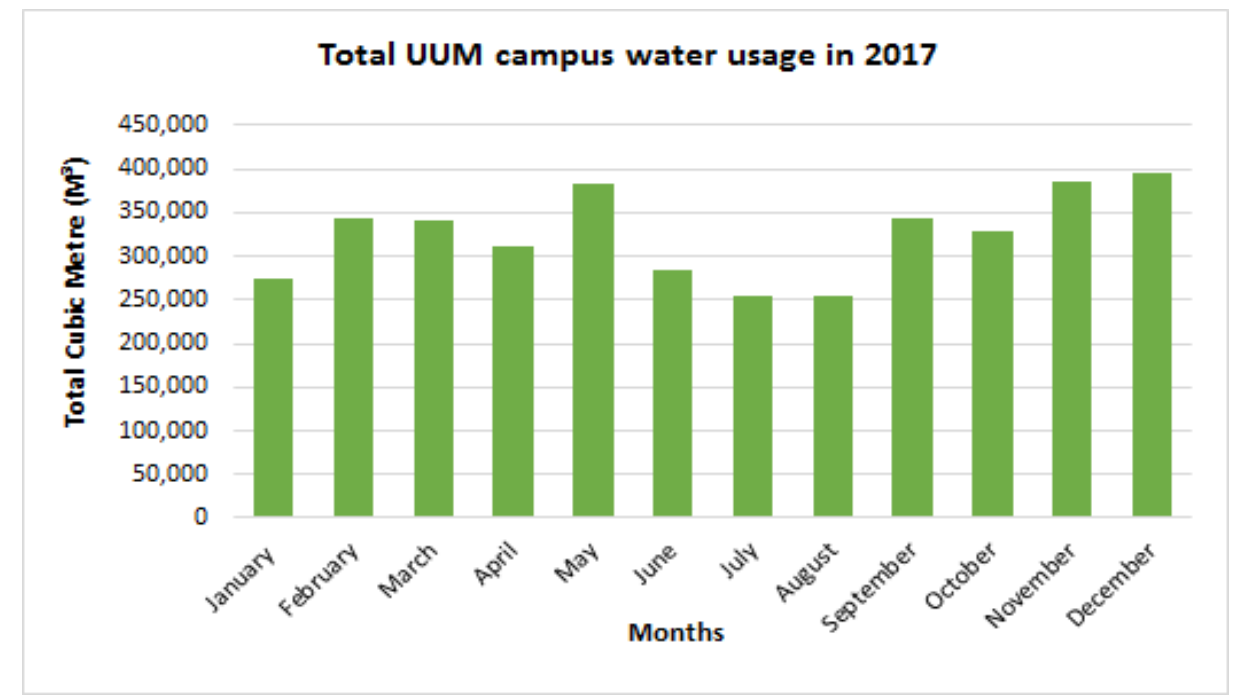

Fig. 2 Total UUM campus water usage in 2017

Water efficient appliances is one of the crucial initiatives needed to control the water consumption and reserve at sustainable level. Through this installation, the campus could manage the water efficiency and wastage issues. However, the university is still in the implementation stage that fully require with devices and systems which eventually will give benefits for water efficiency. 


\section{WATER MANAGEMENT FRAMEWORK}

Inefficient in managing water in campus is not only affecting the university operational costs but affecting the continuous development of future citizens and leaders in sustaining our world at large. With the slow economic situation, the university needs to take more proactive steps in controlling unnecessary waste as well as maintaining natural resources in order to prevent more damage. Although most of the concern of the action to reduce cost in terms of monetary, social cost should not to be neglected by the university.

Moving together with UI GreenMetric, UUM has put some actions to address the concern and efforts in contributing for better world in future. At the end of 2018, UUM introduced sustainability and green campus framework aiming at synchronizing all ideas and actions by pulling every available source in campus such as students, staff, technologies as well as surrounding nature resources. Leading by a steering committee who will be responsible to recognize and priorities suitable action, the framework recognizes every element in the campus as an important agent to translate sustainability into real action.

In much specific action on water management, the framework Fig. 3 shows how the execution of program and projects for water management in campus are addressed. UUM through center of excellences (COE), Development and Maintenance Department (DMD), UUM Information Technology (UUMIT) and selected academic schools are in a steering committee that is responsible to plan suitable programs and activities for addressing quality of water in the campus, recognize issues pertaining to this resource, and to continuously monitor and measure the impact all executed programs / activities.

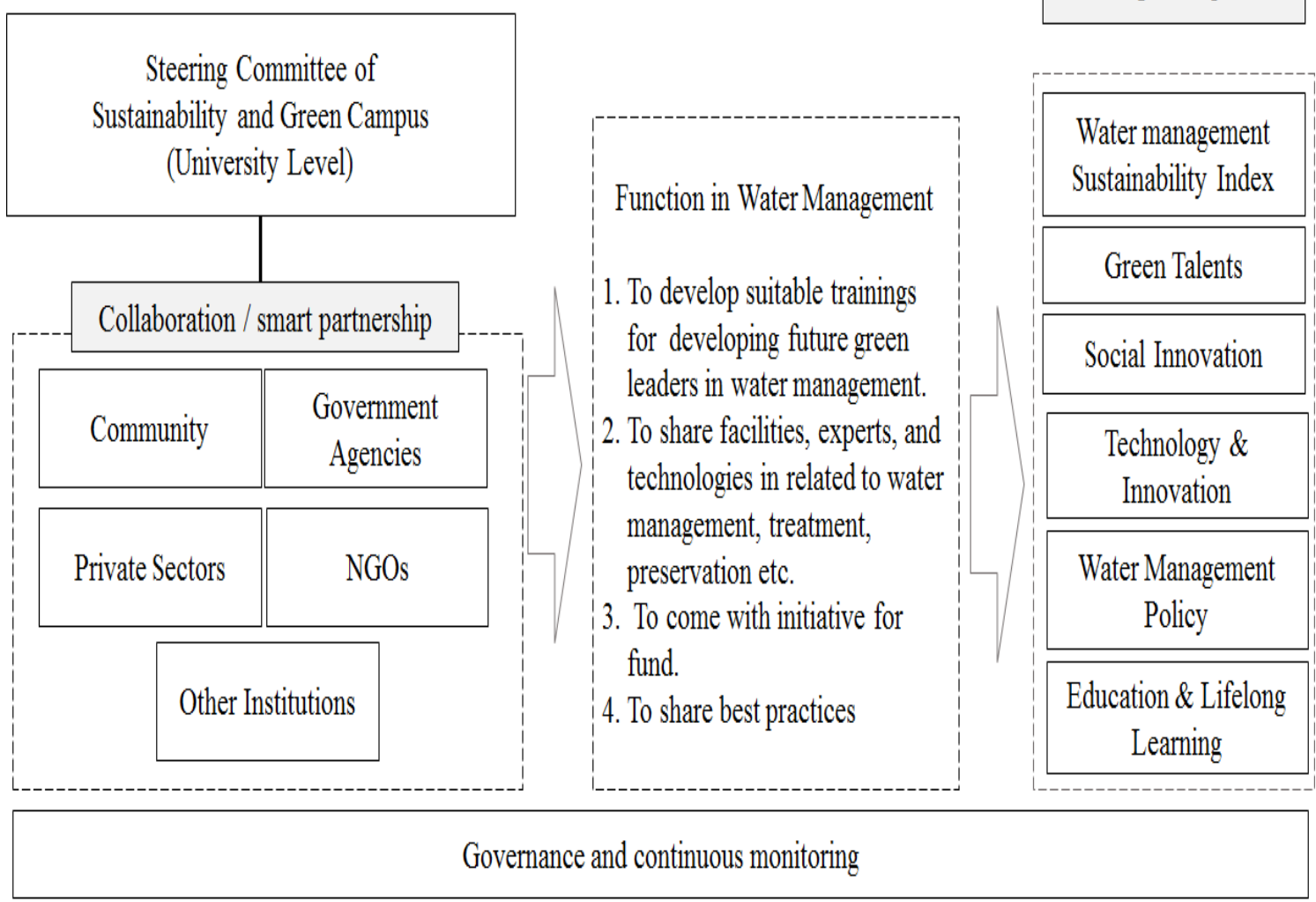

Fig. 3 Framework of water management and sustainability

As we believe that the spirit of preserving the world is not in one hand, therefore we always considering other parties to work closely in our programs or activities. This has been done for two reasons; (i) to share facilities, experts, technologies and even financial in making the programs successful, and (ii) to disseminate the best practices to all hence more people are getting more aware on protecting the resource.

The framework includes monitoring process to value the execution of programs or activities for their sustainability in future. In order to judge fairly all of these efforts, hence it is designed to estimate the social cost so that the impacts on people and environment are also addressed.

\section{IMPLEMENTATION}

The arrangement of programs and activities under the proposed framework has demonstrated cross-sector involvement and expertise in resolving issues related to water management. Table 1 displays some programs which have been executed under the new framework in the campus. All these programs were identified based on citizens' awareness feedback, experts' recommendation, UI GreenMetric assessment, and institutional self-assessment. Proof of implementation also demonstrates the use of more viable project implementation costs with better output.

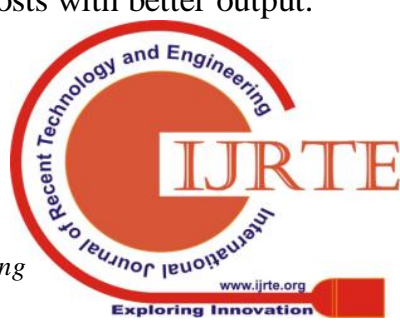


Water Sustainability in Campus: A Framework in Optimizing Social Cost

Table. 1 Executed programs in recent year

\begin{tabular}{|c|c|c|c|}
\hline Program & Goal & Classification & Commitment \\
\hline $\begin{array}{lr}\begin{array}{l}\text { Smart } \\
\text { reticulation } \\
\text { system }\end{array} & \text { leakage } \\
\end{array}$ & $\begin{array}{l}\text { Detect and give early warning } \\
\text { pipeline leakage in academic } \\
\text { zone for reducing water leakage }\end{array}$ & $\begin{array}{l}\text { Research } \\
\text { innovation }\end{array}$ & $\begin{array}{l}\text { Allocation of RM1.3 } \\
\text { million on research grant } \\
\text { and project. }\end{array}$ \\
\hline $\begin{array}{l}\text { Management of food } \\
\text { waste at the lake } \\
\text { restaurant }\end{array}$ & $\begin{array}{l}\text { Avoid river pollution as a result } \\
\text { of waste disposal of food and } \\
\text { plastic }\end{array}$ & $\begin{array}{l}\text { Research } \\
\text { Innovation }\end{array}$ & $\begin{array}{l}\text { Drafting of policy making } \\
\text { to protect the rivers from } \\
\text { pollution. }\end{array}$ \\
\hline harvesting & $\begin{array}{l}\text { Systematic program that supports } \\
\text { a water conservation program }\end{array}$ & $\begin{array}{l}\text { Sustainability project } \\
\text { development }\end{array}$ & \\
\hline $\begin{array}{l}\text { Single-used plastic } \\
\text { campaigns }\end{array}$ & $\begin{array}{l}\text { Minimizing the number of } \\
\text { plastics used in campus and } \\
\text { preventing occurrence of plastic } \\
\text { in the rivers }\end{array}$ & Education & $\begin{array}{l}\text { All UUM citizens and } \\
\text { retails/food providers }\end{array}$ \\
\hline $\begin{array}{l}\text { Replacement of rusty } \\
\text { pipes }\end{array}$ & $\begin{array}{l}\text { Secure clean water consumption } \\
\text { in campus }\end{array}$ & $\begin{array}{l}\text { Sustainability project } \\
\text { development }\end{array}$ & \\
\hline 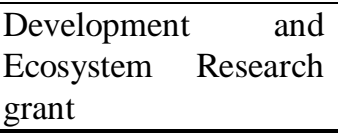 & $\begin{array}{l}\text { Initiative to embark on serious } \\
\text { research activities in area related } \\
\text { to water management }\end{array}$ & $\begin{array}{l}\text { Research } \\
\text { innovation }\end{array}$ & $\begin{array}{l}\text { Total amount of RM50 } \\
\text { thousands and rolling } \\
\text { project amount RM50000 }\end{array}$ \\
\hline
\end{tabular}

The estimation on social cost is different from one program to another program. In general, the social cost is estimated from the total of the overall institutional cost (or personal cost) and external cost. The institutional cost is the incur amount of money spent by the university including commitments for a program, such as purchasing new equipments, payment of salary etc. While, the external cost includes impact of the program to citizen, environment, and related groups. For example, if the rusty pipes are being ignored, the external costs to citizens would be water pollution and risk of drinking contaminated water, health costs, and plant damage caused by water leakage.

\section{SUMMARY}

Overall, the experience in participating UI GreenMetric has created some concerns and responsibility to protect our world even in a university territorial. This has led UUM to re-look at our strengths and developed a framework for delivering better sustainability programs. We use our campus as a test bed, but the intention is to replicate successful programs or ideas with community and government in a hope to have a better and safe place for our generation to live.

\section{REFERENCES}

1. Federal Reserve Bank San Francisco. 2019. What is the difference between private and social costs, and how do they relate to pollution and production? Available online at

https://www.frbsf.org/education/publications/doctorecon/2002/november/private-social-costs-pollution-production/

2. Malaysia Department of Statistics. 2017. Compendium of Environment Statistics. Available online at https://www.dosm.gov.my

3. United Nation. 2017. Goals 6: Ensure access to water and sanitation to all. Available online at

https://www.un.org/sustainabledevelopment/water-and-sanitation/

4. Weifeng Li, Wencui Ling, Suoxiang Liu, Jing Zhao, Ruiping Liu, Qiuwen Chen, ZhiminQiang, Jiuhui Qu. 2011. Development of systems for detecting, early warning, and control of pipeline leakage in drinking water distribution: A case study. Journal of Environmental Sciences, Volume 23 (11), 1816 - 1822. 